\title{
FILM DOKUMENTER EKSISTENSI TARIAN DAN KESENIAN SAKRAL WAYANG WONG DESA ADAT SIDAN
}

\author{
I Nyoman Anom Fajaraditya Setiawan ${ }^{1}$, I Nyoman Widhi Adnyana ${ }^{2}$, \\ Komang Redy Winatha ${ }^{3}$, I Nyoman Yoga Trisemarawima ${ }^{4}$ \\ 1,2,3,4 STMIK STIKOM Indonesia, Denpasar \\ anomkojar@stiki-indonesia.ac.id ${ }^{1}$, manwidhi@stiki-indonesia.ac.id ${ }^{2}$, \\ redywin@gmail.com ${ }^{3}$,yoga.tsw@gmail.com ${ }^{4}$
}

\begin{abstract}
Abstrak
Seni pertunjukan wayang wong adalah salah satu kesenian di Bali dan masih ditarikan di daerah desa tradisional Sidan, Kecamatan Petang, Kabupaten Badung, Bali. Kesenian wayang wong ini menjadi menarik, karena merupakan salah satu kesenian yang dianggap sakral oleh masyarakat setempat. Tetapi di Desa Sidan, wayang wong hanya ditarikan saat upacara keagamaan khusus. Pada prosesi sebelum pertunjukan ditarikan oleh masyarakat setempat, dilakukan ritual khusus pada para penari. Pengamatan lapangan tidak ditemukan adanya dokumentasi dalam bentuk apapun yang mengacu pada rangkaian acara tersebut, termasuk foto ataupun rekaman video. Berdasarkan wawancara dengan kelompok penari, regenerasi dilakukan dari generasi ke generasi secara langsung. Tidak adanya dokumen fisik atau digital, memotivasi tindak lanjut untuk mengeksplorasi fenomena kesenian ini. Metode kualitatif melalui pengumpulan data observasi tempat rangkaian prosesi kesenian wayang wong dan wawancara dilakukan pada anggota penari serta pimpinan desa adat yang mengetahui eksistensi kesenian ini. Kemudian dikomparasikan dengan proses perancangan video, sehingga didapatkan rangkaian cerita dalam bentuk film dokumenter. Finalisasi film dokumenter kemudian didelegasikan secara langsung pada masyarakat setempat, sehingga dapat digunakan sebagai acuan kajian lebih lanjut oleh para akademisi ataupun praktisi seni. Hal ini bertujuan untuk melestarikan kesenian wayang wong sakral yang telah langka di Bali.
\end{abstract}

Kata Kunci: film, dokumenter, tari, wayang wong, Bali

\begin{abstract}
Wayang wong performance art is one of the arts in Bali and is still danced in the traditional village area of Sidan, Petang District, Badung Regency, Bali. Wayang wong art is interesting because it is one of the arts that are considered sacred by the local community. But in Sidan Village, wayang wong is only danced during special religious ceremonies. In the procession, before the performance was danced by the local community, a special ritual was performed for the dancers. Field observations were not found in any form of documentation that refers to the series of events, including photographs or video recordings. Based on interviews with dancer groups, regeneration is carried out from generation to generation directly. The absence of physical or digital documents motivates follow-up to explore this artistic phenomenon. The qualitative method was through observation data collection where a series of wayang wong art processions and interviews were conducted with dancers and traditional village leaders who knew the existence of this art. Then it is compared with the video design process so that a series of stories is obtained in the form of a documentary film. The finalization of the documentary was then delegated directly to the local community so that it could be used as a reference for further studies by academics or arts practitioners. It aims to preserve the art of the sacred wayang wong which has been rare in Bali.
\end{abstract}

Keywords: film, documentary, dance, wayang wong, Bali 


\section{PENDAHULUAN}

Seni budaya di Indonesia merupakan kekayaan yang tak ternilai yang tersebar di segala penjuru bangsa ini. Kekayaan dalam khasanah seni budaya tersebut memberikan dampak positif sebagai magnet pariwisata di Indonesia. Keragaman identitas dan karakteristik seni budaya masing-masing daerah, menjadi keunikan aset berharga yang telah diwariskan sejak lama. Khususnya di Bali, seni budaya sangat mendarah daging pada masyarakatnya. Berkesenian seolah menjadi bagian keseharian masyarakat di Bali. Setiap wilayah pun memiliki karakteristik yang berbeda pada keseniannya. Namun kesenian yang ada di Bali, secara umum dikategorikan menjadi tiga jenis yaitu tarian untuk tontonan atau balih-balihan, tarian untuk upacara atau bebali, dan tarian sakral atau wali (Taksu, 2019).

Tarian yang bersifat sakral ditampilkan secara khusus dalam upacara keagamaan di Bali. Kesenian sakral, pada beberapa tempat memiliki kekhususan prosesi dan pementasan oleh masyarakat desa adat setempat. Iringan prosesi tersebut sangat menarik untuk diulas dan didokumentasikan sebagai dokumen pelestarian seni budaya. Salah satu seni sakral yang masih dapat dilihat keberadaannya adalah kesenian wayang wong di desa adat Sidan Kecamatan Petang Kabupaten Badung Provinsi Bali. Tidak banyak sumber tertulis yang menjabarkan tentang desa adat Sidan. Pada kategori plot cerita, kesenian ini mengarah pada sedratari wayang wong. Wayang wong adalah salah satu kesenian langka di Bali, namun di desa adat Sidan eksistensi kesenian ini didukung oleh elemen masyarakat desa adat.

Wayang Wong adalah nama sebuah drama tari yang terdapat di beberapa daerah di Indonesia. Di Bali, Wayang Wong merupakan drama tari bertopeng yang menggunakan dialog Bahasa Kawi yang selalu menampilkan Wiracarita Ramayana (Soedarsono, 2002). Sebenarnya wayang Wong di Bali terbagi menjadi dua jenis yaitu Wayang Wong Parwa dan Wayang Wong Ramayana. Perbedaannya terletak terutama pada dua hal yaitu Wayang Wong Parwa mengambil lakon dari Wiracarita Mahabharata, sedangkan Wayang Wong Ramayana mengambil lakon dari Wiracarita Ramayana. Semua pelaku (pemegang peran) dalam Wayang Wong Parwa (kecuali panakawan) tidak memakai tapel atau topeng, sedangkan Wayang Wong Ramayana sebaliknya semua memakai tapel. Pada perkembangan selanjutnya yang dimaksud Wayang Wong di Bali adalah Wayang Wong Ramayana tersebut dan Wayang Wong Parwa disebut Parwa saja (Bandem, 1983). Sumber dari Bandem memiliki pemahaman yang mirip dengan kutipan sebelumnya, namun lebih berkembang tidak hanya pada cerita pelakonan Ramayana, tetapi dapat dipentaskan pula pada epos cerita Mahabharata. Relevansi sumber dari Soedarsono, Bandem dan Murgiyanto adalah wayang wong sebuah tari topeng yang memiliki cerita dari epos Ramayana, seperti halnya yang kesenian wayang wong di Desa Adat Sidan. Cerita ini mengisahkan peperangan antara Rama, Raja Ayodya melawan Rahwana, Raja Alengka. Demikian terkenalnya cerita Ramayana ini di Indonesia, sehingga mendorong hati para pujangga dan seniman untuk mengabadikannya ke dalam berbagai bentuk karya seni (Bandem, 1996). 
Hasil kajian terkait lainnya menyebutkan wayang wong merupakan sebuah pementasan teater, yaitu dalam pengertiannya memiliki lakon, aktor, naskah dan berbagai macam alat pendukung pertunjukannya (Supendi, 2007). Ekspresi budaya tradisional wayang wong semestinya memiliki hak cipta untuk keberlangsungannya kedepan (Kusharyani, M.; Santoso, 2016). Pada kajian tersebut memiliki relevansi pada sisi pagelaran serta pentingnya sebuah hak cipta pada karya pertunjukan, namun hal tersebut tentunya membutuhkan media sebagai bukti rekaman untuk melangkah lebih lanjut. Pelestarian pun menjadi diskursus penting jika membicarakan permasalahan budaya, seperti halnya membuat media pembelajaran (Sonalitha, Yuniarti, Prihatiningsih, \& Prasetya, 2017), tetapi pengumpulan bahan yang dalam hal ini mengkhusus pada pertunjukan wayang wong adalah hasil dokumentasi awal yang kemudian dapat dikembangkan menjadi berbagai media pengembangan.

Pentingnya pelestarian budaya tersebut senada dengan pengertian kesenian wayang wong yang merupakan rangkaian cerita dalam bentuk tarian, ditarikan secara turun temurun oleh setiap generasi dan dilatih oleh penari senior yang telah menarikan tarian tersebut sebelummya. Melestarikan warisan leluhur maka dipilihlah anak muda agar mereka mengetahui pakem tari wayang wong Desa Sidan ini (Badung, 2019). Pemilihan penari dalam pelakonan wayang wong tergolong cukup sulit, karena pada masa sekarang terjadi penurunan kesadaran generasi baru yang berminat untuk mempelajari kesenian ini. Dikatakan oleh ketua penari wayang wong, selain sulitnya membangun regenerasi, kesulitan lain adalah ketiadaan dokumentasi dalam bentuk apapun sebagai sarana media presentasi. Sehingga informasi dilakukan secara oral pada saat dilakukannya perekrutan dan pelatihan tari wayang wong. Tiadanya dokumentasi merupakan hal yang sangat fatal pada era digital ini, dikarenakan informasi berharga yang telah ada dapat raib begitu saja. Keprihatinan ini menjadikan pemicu untuk membuat sebuah dokumentasi yang mengangkat cerita tentang kesenian wayang wong di desa adat Sidan Kecamatan Petang. Adanya dokumentasi juga memberikan kesempatan pada generasi baru penari wayang wong di desa adat Sidan, untuk lebih mengenal tarian dari kesenian sakral tersebut. Media dokumentasi secara digital kesenian ini juga dapat terpelihara dan diteruskan pada media pendukung lainnya agar tidak sirna termakan jaman.

Salah satu media dokumentasi digital adalah video. Video dapat diasumsikan sebagai perekaman dalam transmisi, frekuensi video yang dapat diterima pada televisi. Hal ini terkait pula dengan tindakan dokumentasi dalam bentuk video recording. Proses kerja dari video ini, selain sebagai dokumentasi juga dilakukan pada kebutuhan broadcasting (Setiawan, 2018). Tidak hanya itu, video memiliki ragam jenis genre dan salah satunya adalah dalam bentuk dokumenter. Dokumenter merupakan genre non-fiksi yang terfokus mengangkat dokumentasi aspek-aspek realitas dalam alur ceritanya (Setiawan, 2018), sehingga dirasa sangat relevan digunakan untuk mengangkat fenomena kesenian wayang wong yang dibahas dalam penelitian ini. 
Adanya fenomena yang ada pada kesenian sakral wayang wong di desa Sidan tersebut, memotivasi untuk dilakukannya prosedur dokumentasi menyeluruh. Selain mengangkat prosesi dan pertunjukan wayang wong Desa Adat Sidan, mengangkat pula tentang motivasi dibalik pertunjukan serta pelestarian kesenian ini. Oleh sebab itu, unsur motivasi digunakan pula dalam menggali informasi yang dibutuhkan. Motivasi, dari pengertiannya menurut Frence dan Reven, adalah suatu yang mendorong seseorang untuk menunjukkan perilaku tertentu (Sule, Ernie Tisnawati \& Saefullah, 2006). Menurut Hisbuan, motivasi (motif) sering kali disamakan dengan dorongan. Dorongan atau tenaga tersebut merupakan gerak jiwa dan jasmani untuk berbuat, sehingga motif tersebut menggerakkan manusia untuk bertingkah laku dan perbuatan itu mempunyai tujuan tertentu. Pendapat tersebut didukung oleh Jones, mengatakan motivasi mempunyai kaitan dengan suatu proses yang membangun dan memelihara perilaku kearah suatu tujuan (Sutrisno, 2009). Relevansi wacana tersebut yaitu berhubungan pada ada alur cerita dokumenter dalam bahasan penelitian ini. Dokumentasi ini akan menjadi sebuah dokumenter yang akan menjadi inventaris desa yang berharga dan sekaligus sebagai media presentasi untuk berbagai tujuan. Dokumenter ini pula niscaya akan menjadi media dalam misi pelestarian seni budaya terutama terkait kesenian sakral wayang wong di Bali.

\section{METODE PENELITIAN}

\subsection{Metode Pengumpulan Data}

Penelitian ini menggunakan metode pendekatan kualitatif dengan mengungkap fenomena yang unik terjadi pada individu, kelompok, ataupun organisasi dalam suatu masyarakat secara rinci serta mendalam sehingga dapat dipertanggungjawabkan secara ilmiah (Basrowi, 2002). Data yang didapatkan kemudian dikomparasikan dengan kajian sumber, dengan landasan teori terkait, dan dianalisis dengan struktur model penelitian. Guna memperoleh data yang sesuai dengan tujuan penelitian, maka diperlukan studi lapangan dan studi pustaka yang bertujuan untuk mengetahui topik yang terkait. Data awal sebagai landasan teori dipergunakan untuk menganalisis data yang diperoleh di lapangan untuk mendapatkan kesimpulan data. Kesimpulan data dianalisis untuk memperoleh kesimpulan umum dan kesimpulan khusus penelitian, bertujuan menjawab pertanyaan penelitian yang berupa asumsi dan mencapai tujuan penelitian. Berikut adalah faktor penting dari rancangan penelitian :

a) Penelitian langsung di lapangan dilakukan untuk mendapatkan data primer dan penelitian kepustakaan untuk mendapatkan data sekunder. Penelitian kepustakaan dilakukan terhadap bahan-bahan bacaan dalam bentuk buku, majalah, bahan seminar, koran, majalah, katalog dan sumber tertulis lainnya yang terkait dan relevan dengan landasan teori. Sumber-sumber audio visual dari wawancara dengan seniman tari wayang wong dan perangkat desa yang berkompeten untuk menyempurnakan dan melengkapi kebutuhan data.

b) Pencarian sumber-sumber data mempergunakan metode purposive sampling. Datadata tersebut akan diinterpretasikan dan dideskripsikan secara komperatif.

Penelitian kualitatif ini menggunakan sumber data dari informan yang dikategorikan menjadi informan kunci dan informan pelengkap. Informan kunci adalah para penari 
senior wayang wong di desa adat Sidan Petang Badung. Sedangkan informan pelengkap adalah perangkat desa berkompeten yang benar-benar mengetahui riwayat seni sakral wayang wong di desa adat Sidan. Kedua jenis sumber data ini terfokus pada kesenian wayang wong desa adat Sidan.

\subsection{Asumsi Penelitian}

Asumsi berdasarkan literatur, wayang wong merupakan sebuah tarian yang mengambil cerita dari epos Mahabhrata dan Ramayana. Namun wayang wong yang ditarikan di Desa Sidan secara khusus menggunakan pakem cerita Ramayana. Sedangkan sumsi yang dapat ditarik penelitian berdasarkan observasi dan wawancara di lapangan adalah tarian wayang wong di desa adat Sidan merupakan kesenian yang disakralkan oleh masyarakat adat Sidan Kecamatan Petang Kabupaten Badung. Pementasan wayang wong tersebut hanya dipentaskan pada hari tertentu menurut penanggalan Bali. Pementasan dilakukan pada tempat persembahyangan atau pura di desa adat setempat dan disaksikan oleh masyarakat. Pelakonan dalam kesenian wayang wong ini diambil dari penggalan cerita epos ramayana. Sebelum pementasan, dilakukan beberapa prosesi penting yang dijalani oleh para penari yang terlibat serta masyarakat adat di desa adat Sidan. Persembahyangan dilakukan pada pura sekitar desa adat, prosesi pembersihan diri para penari dan sederet prosesi lain yang dianggap penting. Setelah dijalaninya prosesi maka pementasan tari sakral wayang wong dilakukan di pelataran pura desa adat yang ditunjuk berdasarkan parum atau rapat adat.

Perekaman data untuk mendokumentasikan pagelaran seni pertunjukan ini memerlukan beragam alat. Kebutuhan alat yaitu alat yang mendukung perekaman video yang berkualitas baik. Penggunaan bantuan lampu pencahayaan sebagai penerangan untuk menyempurnakan perekaman video menjadi pertimbangan penting. Alat perekaman, yakni alat untuk merekam video agar hasil rekaman yang didapatkan berkualitas baik. Setelah data rekaman dari pengumpulan data primer didapatkan, kemudian disusun sebuah script atau skenario yang bertujuan agar narasi pada video dokumenter ini nantinya dapat tersaji dengan baik. Gambar penceritaan atau storyboard dibuat untuk memantapkan pengambilan gambar dan proses penyatuan atau mixing video pada akhir finalisasi proses perancangan dokumenter. Video dokumenter yang dihasilkan nantinya, akan di sumbangkan pada desa adat Sidan sebagai dokumen desa, sumber kajian berikutnya, dan sarana pelestarian kesenian sakral wayang wong di desa adat Sidan.

\section{HASIL DAN PEMBAHASAN}

Pada bab ini dibahas secara runut proses dari observasi, pengumpulan data pada setiap lokasi, wawancara pada informan, struktur pola pikir berdasarkan analisis dan sebagainya yang berkaitan dengan luaran penelitian.

\subsection{Peta Lokasi Penyebaran Informan}

Penggalian data dari informan tersebar di beberapa tempat yaitu berlokasi pada rumah kediaman dari ketua kelompok penari wayang wong, beberapa tempat persembahyangan desa setempat, dan balai desa atau bale banjar. Lokasi tersebut 
berjarak berdekatan satu sama lain dan masih dalam lingkup wilayah Desa Adat Sidan. Sebaran lokasi tempat penggalian data dapat dilihat pada gambar 1 agar dapat tergambarkan keadaan kondisi lingkungan dan situasi lapangan yang dimaksud.

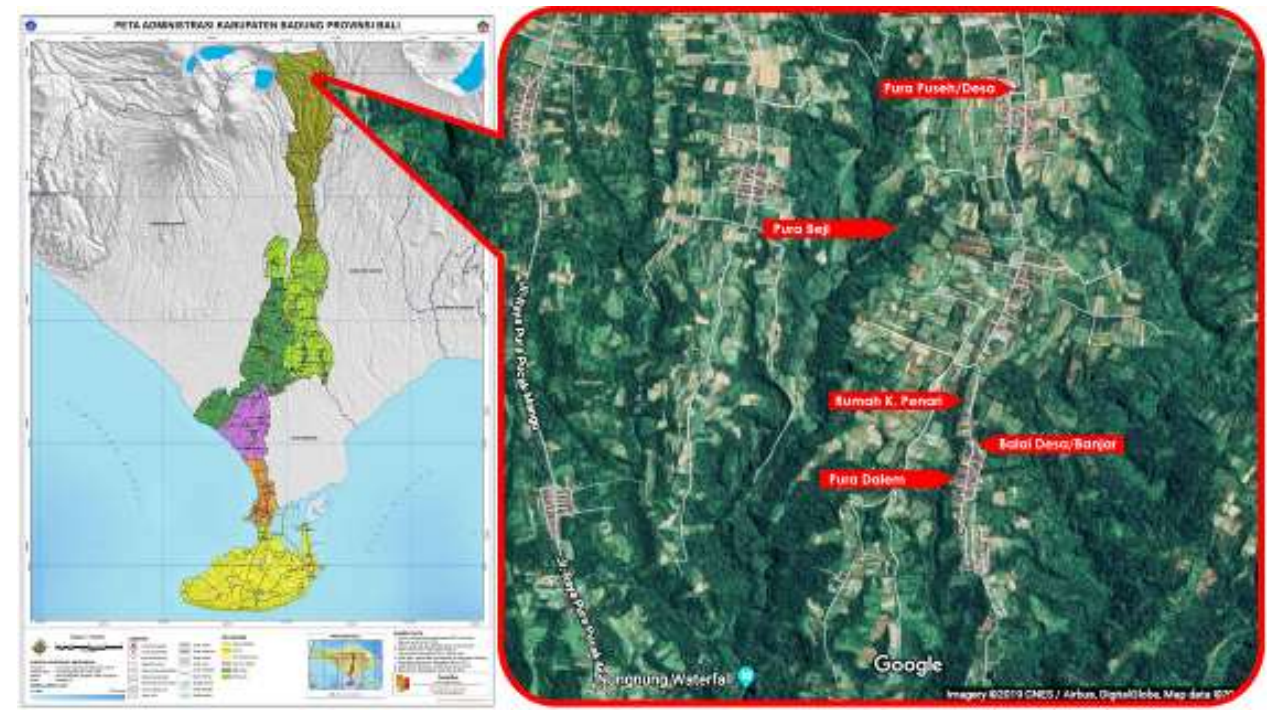

Gambar 1. Pemetaan sebaran lokasi penggalian data.

[Sumber: Google Map dan data penelitian]

Pada gambar 1 terlihat sebaran lokasi pada dataran tinggi di wilayah Desa Adat Sidan. Berdasarkan peta administratif Kabupaten Badung dan penginderaan Google Map dapat menjelaskan pula gambaran umum tentang lokasi diantaranya dapat dijelaskan sebagai berikut (gambar 2):

a) Pura Puseh/Desa pada Desa Adat Sidan sebagai lokasi pengambilan dokumentasi prosesi persembahyangan yang dilakukkan seluruh masyarakat desa sebelum pementasan wayang wong sakral yang bertujuan untuk memohon keselamatan dan kelancaran pementasan yang bersifat sakral.

b) Pura Beji pada Desa Adat Sidan yaitu sebuah tempat suci pada sumber mata air dalam prosesi pengambilan air suci sebagai sarana pembersihan raga dan desa sebelum pementasan wayang wong.

c) Kediaman ketua kelompok penari atau secara tradisional yang disebut dengan kelian sekaa sebagai salah satu informan kunci dalam dokumenter yang akan dibuat.

d) Balai desa atau bale banjar sebagai tempat mendokumentasikan kelompok penari dalam berbagai kegiatan persiapan pertunjukan, termasuk dalam proses diskusi anggota penari, latihan tabuh, vokal dan tarian.

e) Pura Dalem adalah tempat persembahyangan masyarakat desa setempat, dalam hal ini sekaligus sebagai tempat penyimpanan topeng wayang wong yang disakralkan dan tempat pementasan tarian wayang wong. 


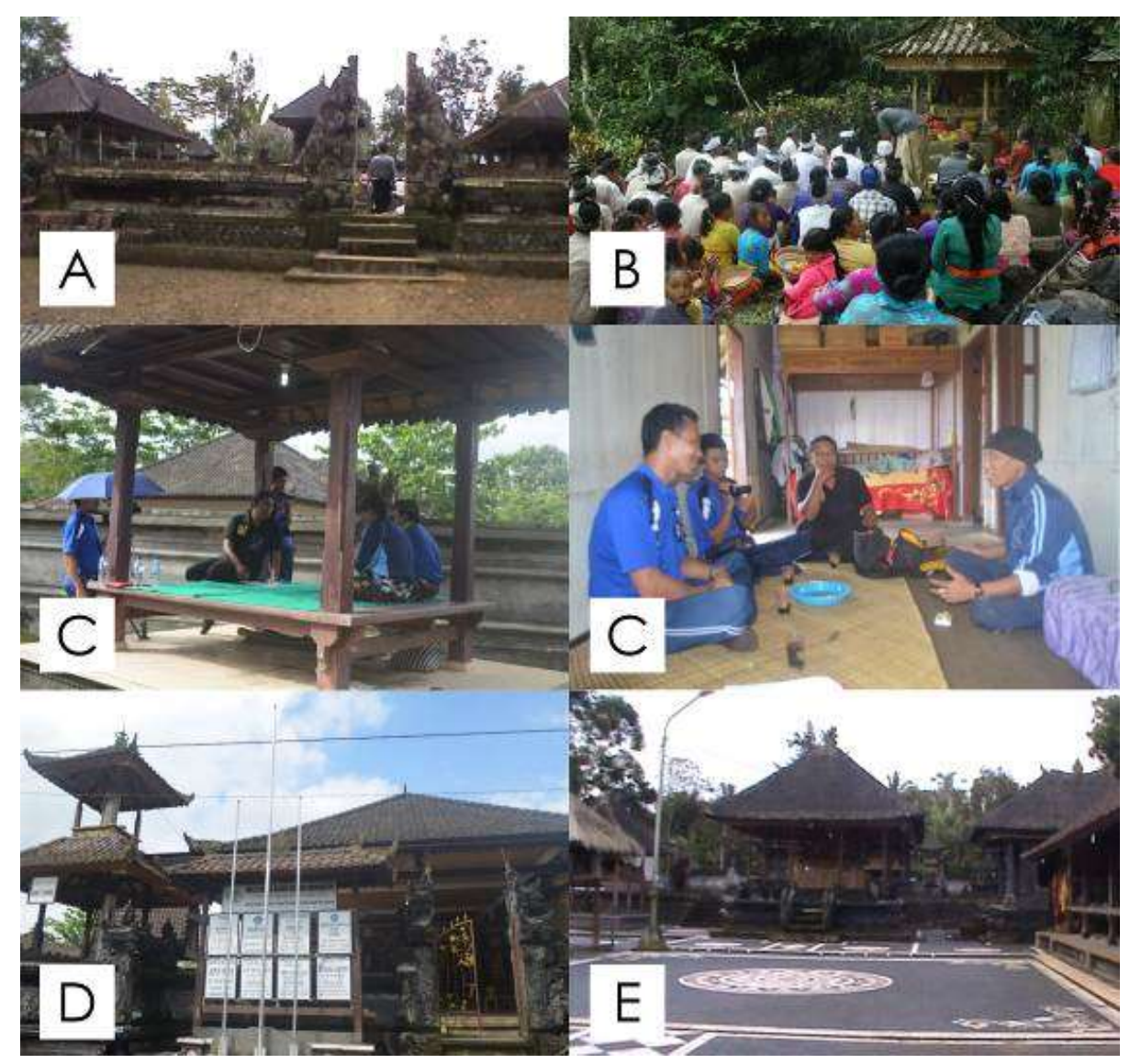

Gambar 2. Situasi lapangan dari penjelasan sub a sampai e (kiri ke kanan).

[Sumber: dokumentasi Anom Fajaraditya]

\subsection{Penyebaran Informan dan Kriterianya}

Berdasarkan metode pengumpulan data, beberapa hal penting dilakukan yang bertujuan untuk mempersiapkan dokumentasi yang lebih terarah dan terencana pada saat pementasan. Pengumpulan data ini juga terkait dengan jabaran yang dijelaskan pada pemetaan gambar 1 yang yang dilakukan secara bertahap dan dikomparasikan dengan data wawancara dan observasi. Pada hasil data dan informasi yang didapatkan berkembang pada pemetaan proses persiapan pengambilan gambar pada hari yang nantinya disepakati.

Kriteria informan adalah hal yang sangat penting untuk dipertimbangkan pada pembuatan dokumenter ini. Sebagai bagian sumber yang penting, informan yang dicari dan digali untuk beragam informasinya adalah informan-informan kunci yang memiliki pengetahuan mendalam tentang topik yang diangkat. Kriteria informan yang menjadi pertimbangan pemilihan dan penggalian data adalah sebagai berikut:

a) Memiliki pengetahuan tentang wayang wong Desa Adat Sidan.

b) Informan merupakan bagian langsung dari aktifitas atau prosesi yang berhubungan dengan wayang wong yang dimaksud.

c) Segala data ataupun informasi dalam bentuk wacana ataupun tertulis dapat dipertanggung jawabkan oleh informan. 
Wawancara awal dilakukan kepada ketua penari atau disebutkan kelian sekaa (kelompok) yang bernama I Gede Gimaryuda, beliau menyebutkan bahwa kelompok penari wayang wong ini dinamakan "Sekaa Batel" yang beranggotakan seluruh masyarakat dari Desa adat Sidan yang ikut menarikan tari wayang wong yang dimaksud. Pada kesempatan wawancara berikutnya pada Gimaryuda, dijelaskan bahwa anggota penari atau pelatih tari beraktifitas secara sukarela dan atas dukungan desa adat. Sebelum tarian dipertunjukkan pada masyarakat, tentunya para pelaku harus melalui proses latihan, persembahyangan pada tempat suci desa setempat dan melalui prosesi pembersihan raga atau mewinten. Penjelasan dari Gimaryuda didukung pula oleh salah satu pengurus lainnya dari sekaa yaitu I Wayan Budiasa serta memaparkan ciri khas dari tarian wayang wong.

Pada kesempatan yang berbeda, wawancara dilakukan pada Ketua Adat atau secara tradisional disebut dengan bendesa yaitu I Made Wirta. Beliau mengatakan bahwa sejarah adanya tarian sakral wayang wong dari Desa Adat Sidan tidak diketahui muasalnya dan telah diwarisi secara turun temurun. Sedangkan penari dan pementasan tarian wayang wong dilakukan dalam sehari dengan mengadakan beberapa tahapan prosesi serta hari baik. Pementasan dilakukan di hadapan masyarakat desa setelah dilakukan proses persembahyangan bersama. Namun proses latihan tergolong cukup panjang, dilakukan berbulan-bulan bersama segenap pelaku baik penari dan penabuh. Perekrutan penari dan penabuh dilakukan dengan kekeluargaan dan kebersamaan sehingga proses tersebut diharapkan membangun minat generasi berikutnya untuk mewarisi kembali kesenian wayang wong ini. Sebagai ketua adat beliau juga mengharapkan pamerintah untuk ikut serta dan tetap memperhatikan pula keberlangsungan kesenian wayang wong dari Desa Adat Sidan ini.

\subsection{Analisis Data Kolektif}

Berdasarkan pengumpulan data primer, dapat ditarik analisis sebagai acuan langkah selanjutnya. Analisis yang dimaksud dalam hal ini adalah rencana pendokumentasian dari aktivitas penting yang terkait dengan pementasan wayang wong. Analisis ini merupakan rangkaian kronologi tindakan atau aktivitas dalam memilah kejadian untuk kebutuhan dokumenter. Kronologi aktivitas pendokumentasian wayang wong tersebut dijabarkan sebagai berikut:

a) Setelah adanya wawancara awal pengumpulan data kelian sekaa mulai berkoodinasi kepada bendesa adat dengan maksud mementaskan tarian wayang wong. Mengingat bahwa sudah waktunya untuk dipentaskan sekaligus sebagai dimaknai pembersihan lingkungan desa.

b) Kordinasi dengan bendesa menghasilkan hari penentuan parum desa atau rapat besar di balai desa sehingga masyarakat ikut duduk bersama menentukan hari baik pementasan.

c) Kelian sekaa berikutnya berkoordinasi dengan pengurus sekaa serta termasuk anggota, untuk menyiapkan diri menghadapi hari pementasan yang belum ditentukan. Hal ini termasuk perekrutan dan persiapan awal anggota baru. 
d) Setelah dilakukannya rapat di balai desa dan mendapatkan keputusan hari baik pementasan, maka ditentukan panitia pementasan oleh masyarakat untuk mempersiapkan kebutuhan prosesi yang akan dijalani.

e) Pada hari yang ditentukan serta persiapan yang baik maka prosesi upacara sebelum pementasan adalah melakukan persembahyangan ke Pura Puseh Desa. Prosesi ini untuk memohon ijin kepada Tuhan sekaligus mendoakan kelancaran prosesi pementasan wayang wong. Pada prosesi ini dan berikutnya selalu akan dipantau oleh informan kunci serta pendeta/mangku, pemuka adat dan tokoh masyarakat lainnya.

f) Setelah menunaikan persembahyangan di Pura Puseh, prosesi dilanjutkan ke Pura Beji untuk mencari air dari sumber mata air pada tempat tersebut yang digunakan untuk prosesi selanjutnya. Tempat persembahyangan ini memiliki medan yang cukup berat dan terjal.

g) Setelah melakukan persembahyangan dan penyucian air di Pura Beji, berikutnya prosesi dilakukan di Pura Dalem desa Sidan. Pada Pura ini selain persembahyangan bersama diadakan pula prosesi pawintenan/pelantikan sekaligus pembersihan raga para penari yang mengikuti pementasan.

h) Berikutnya adalah pementasan yang disebut juga dengan istilah sesuhunan napak pertiwi atau diartikan sungsungan turun ke bumi. Pementasan wayang wong sakral ini disaksikan oleh seluruh masyarakat Desa Adat Sidan sampai akhir cerita.

Melihat aktivitas yang ada merujuk pada kegiatan seni budaya yang ada di Kabupaten Badung bagian utara ini tepatnya di Kecamatan Petang maka dirasa perlu menyisipkan dokumentasi pendukung lain yang terkait. Pendukung lain yang dimaksud adalah menjelaskan tentang seni budaya di Badung utara yang memiliki popularitas secara luas. Sisipan ini kemudian mengkrucut dan mengarah pada kesenian Wayang Wong sakral yang ada di Desa Adat Sidan. Jika divisualisasikan dalam bentuk bagan cerita, rangkaian ini akan membentuk bagan segi tiga dan sudut teratas adalah cerita yang mendokumenterkan pementasan wayang wong.

Diawali dengan pembukaan tentang eksistensi seni budaya di Kabupaten Badung secara benda atau artefak yang disucikan dan tempat suci, maupun tak benda seperti tradisi upacara Ngebek Widhi dan tradisi Ngendar. Lalu rankaian cerita mengarah pada prosesi ritual upacara adat tradisional serta berpindah pada kesenian tradisional yang bersifat populer. Bahasan tentang esenian ini diawali dari kesenian topeng yang terkenal pada eranya yaitu kesenian Topeng Tugek yang mengispirasi seniman muda saat ini. Setelah diawali sisipan seni budaya sebelumnya, lalu dilanjutkan pada kesenian wayang wong yang diangkat pada bahasan perancangan ini. Tentunya pada durasi tayang, bahasan wayang wong menjadi bahasan yang paling panjang dan tuntas dari awal prosesi sampai akhir. Bagan pola perancangan yang dimaksud adalah bagan seperti pada gambar 3 .

Berdasarkan keadaan proses wawancara dan observasi yang telah dilakukan, maka dapat diperkirakan keperluan alat yang dibutuhkan selama pra dan saat proses berlangsung. Alat yang dimaksud adalah peralatan yang menunjang perekaman dan memaksimalkan hasil dokumentasi audio maupun video, sehingga hasil pada pasca proses mendapatkan luaran yang maksimal pula. Peralatan yang dibutuhkan tersebut 
secara garis besar meliputi kamera rekam video profesional, alat bantu pencahayaan, peralatan pendukung proses editing, software, hardware, dan peralatan lainnya yang mendukung pembuatan dokumenter ini.

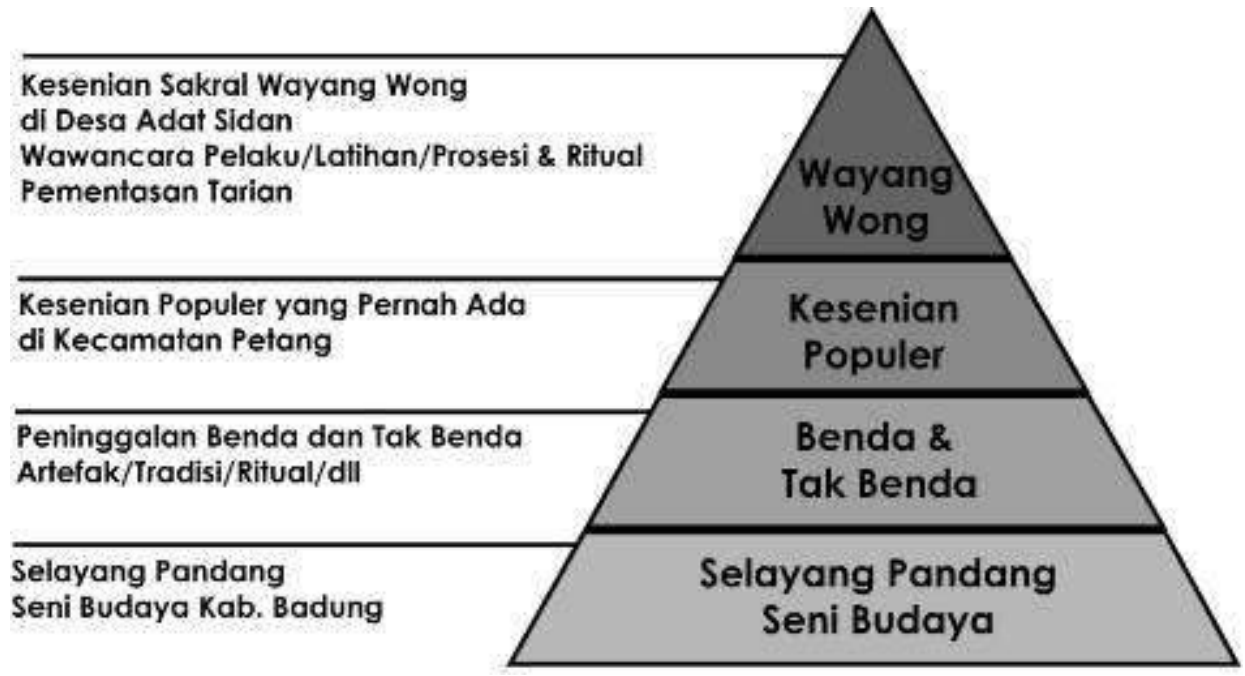

Gambar 3. Struktur pola perancangan.

[Sumber: Dokumentasi Anom Fajaraditya]

\subsection{Pra Perancangan}

Adanya runutan analisis yang telah diprediksikan maka selanjutnya dipersiapkan elemen penting lain dalam perancangan. Pra perancangan yang dimaksud adalah pra proses, yaitu mempersiapkan dokumen pemandu dalam mendokumentasikan kejadian serta keadaan yang ada. Pra proses ini pula memberikan panduan terhadap teknik pengambilan gambar yang musti dilakukan sebelum dan proses pada saat pementasan berlangsung.

Persiapan ini memerlukan dua persiapan inti diantaranya mempersiapkan script atau skenario yang berupa struktur teks sebagai plot cerita pengarahan dokumenter. Pada persiapkan storyboard atau papan penceritaan sebagai bahan pemandu pengambilan gambar serta rencana teknik yang akan digunakan. Segala persiapan sangatlah penting sebagai dasar tindakan yang terencana dilapangan, sehingga pengambilan gambar prosesi dan pementasan wayang wong dapat berjalan efektif dan efisien sesuai arahan awal. Sajian script dan sekaligus storyboard dalam satu tabel dengan durasi awal yang telah direncanakan. Disebabkan oleh keterbatasan waktu observasi dan persiapan pra produksi, maka tabel storyboard disajikan secara tekstual dalam memvisualisasikan citra dan gerak kamera.

\subsection{Perancangan}

Pada proses perancangan, yaitu kelanjutan tindakan yang telah direncanakan pada pra perancangan. Tindakan perangcangan tersebut yaitu merealisasikan segala hal yang tertera pada skenario ke media video dokumenter. Pada proses ini pula dilakukan peengambilan gambar-gambar dalam bentuk gambar bergerak (video) ataupun diam foto, sedangkan perekaman audio dilakukan secara bersamaan. Mengingat perekaman ini tidak dapat diulang dan segala bentuk aktifitas dari sumber data ya, maka peralatan 
dan tim dilapangan pun harus dikoordinasikan dengan baik. Adapun keterangan kualitas dari hasil video dokumenter ini dengan Aspect rasio 16 : 9; Kualitas video DVD HD quality; Durasi prolog 8 menit 15 detik; Durasi latihan 22 menit 31 detik; Durasi pementasan 22 menit 30 detik; Durasi penutup 21 menit 45 detik; Total durasi 1 jam 7 menit 3 detik.

Proses perancangan termasuk dengan proses editing sebagai implementasi pra proses yang telah dijabarkan pada sub bab sebelumnya. Proses ini dilakukan bersama dengan keterlibatan eksekutif produser, depth of photography sebagai kameramen sekaligus editor, ketua peneliti sebagai director atau sutradara, dan anggota peneliti sebagai produser.

\subsection{Pasca Perancangan}

Tindakan perampungan yaitu pendukung dan pengemasan video dokumenter. Setelah video dokumenter rampung pada proses perancangan (editing dan konversi data dalam bentuk file DVD HD), maka langkah selanjutnya adalah mempersiapkan desain mengemas keping DVD dan sampul DVD agar terlihat menarik serta eksklusif. Perancangan pada kemasan ini menggunakan unsur desain diantaranya ilustrasi, tipografi, warna bentuk yang kemudian secara keseluruhan disebut dengan unsur visual dalam ranah ilmu desain komunikasi visual. Berikut adalah tabel unsur visual dari sampul kemasan dvd dan sampul keping dvd ditampilkan pada tabel 1.

Tabel 1. Elemen visual sampul kemasan dan keping DVD.

[Sumber: Dokumentasi Anom Fajaraditya]

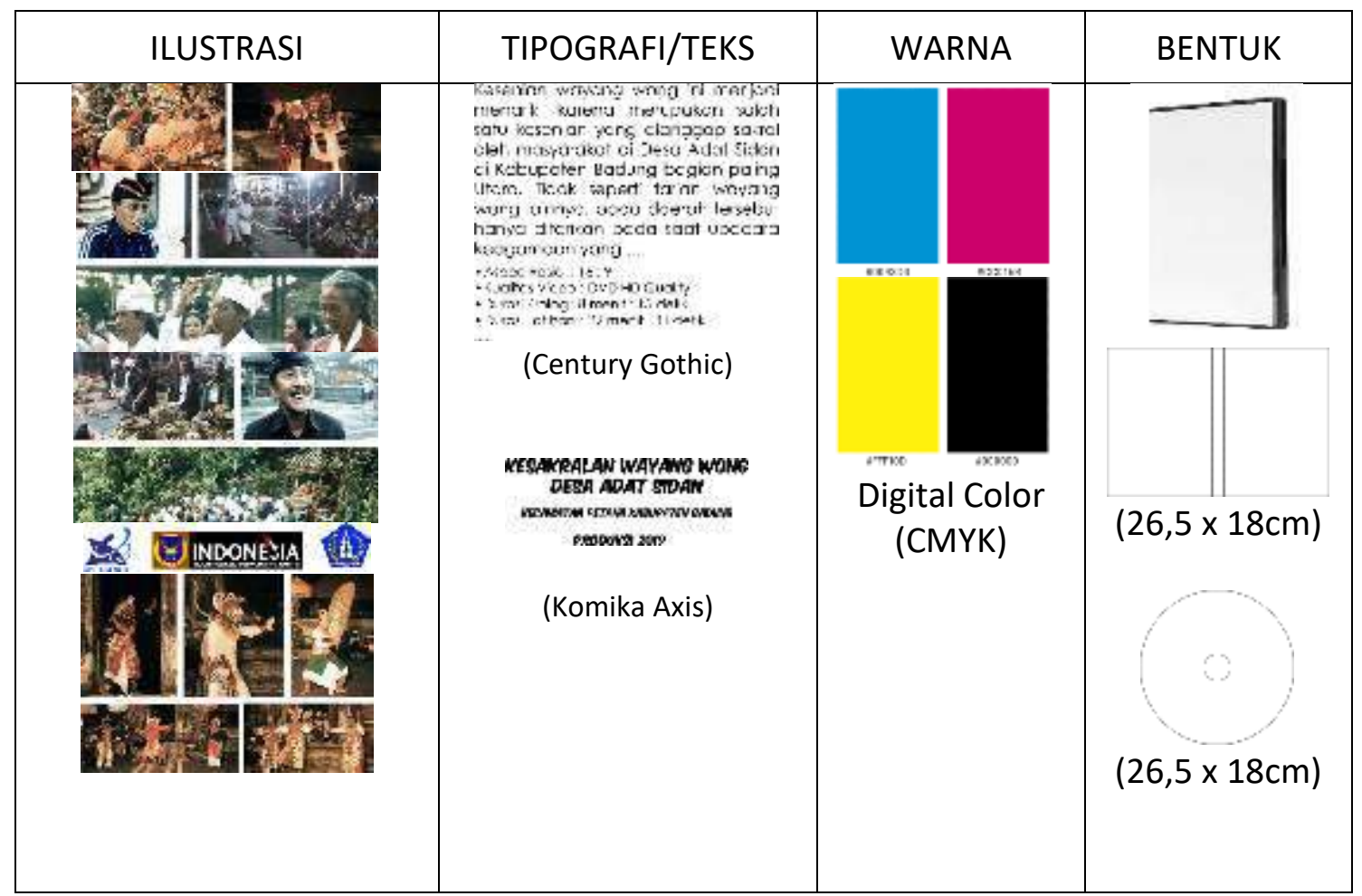


Elemen visual yang ditampilkan memiliki kandungan unsur-unsur desain yang diramu sedemikian rupa yang dapat diterangkan diantarannya:

a) Ilustrasi menjabarkan tentang kandungan unsur gambar pada tiap rancangan.

b) Tipografi menjabarkan kandungan unsur penggunaan dan tata huruf pada tiap rancangan.

c) Warna menjabarkan kandungan unsur tatanan pewarnaan yang digunakan pada rancangan.

d) Bentuk menjabarkan ruang komposisi kombinasi unsur visual pada objek yang telah ditentukan.

Adapun hasil final perancangan berupa visualisasi sampul kemasan video dokumenter ini dapat dilihat pada gambar 4 .

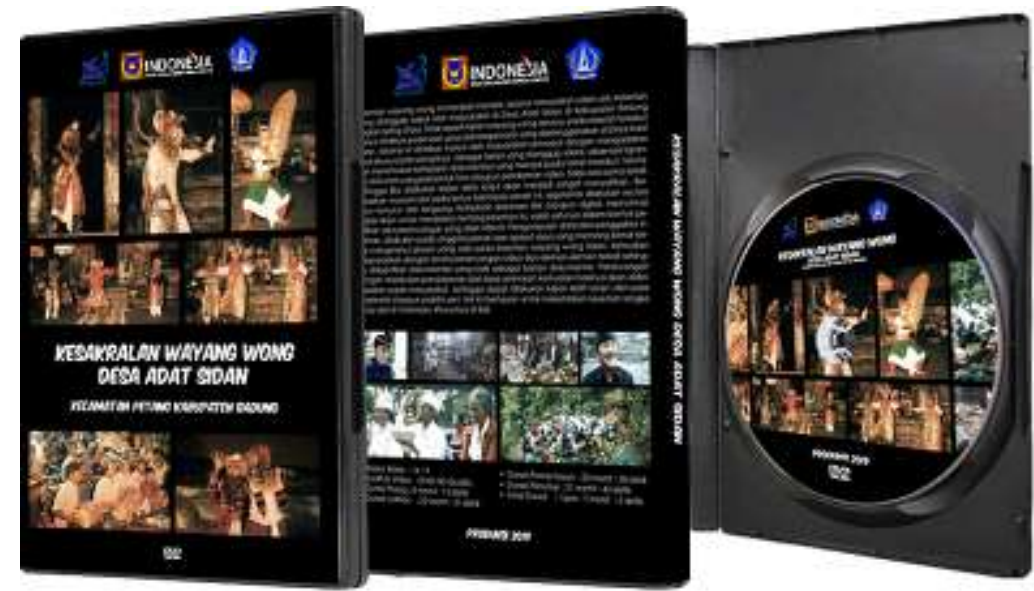

Gambar 4. Visualisasi desain final pada media.

[Sumber: Dokumentasi Anom Fajaraditya]

Menindak lanjuti langkah berikutnya selain editing dan merancang kemasan, penyimpanan data video dokumenter yang ada tidak hanya pada media penyimpanan dalam konversi DVD. Karena keterbatasan ruang penyimpanan data pada keping DVD maka dicari alternatif lain sebagai media penyimpanan yang lebih maksimal yaitu pada flash disk dengan kapasitas yang lebih besar. Pada media penyipanan flash disk ini tersimpan data-data kolektif yang lebih lengkap sebagai master data video dokumenter. DVD video dokumenter dan data mastering dalam bentuk flash disk akan diserahkan kepada ketua Sekaa Batel wayang wong Desa Adat Sidan. Kemudian media tersebut disalurkan pada tetua desa atau pihak terkait sebagai bagian inventaris desa yang terkait dengan wayang wong pada Desa Adat Sidan. Video dokumenter yang dibahas dalam artikel ini dapat pula dilihat secara spesifik pada tautan https://www.youtube.com/watch?v=tLpXbrU71Ks\&t=1808s.

\subsection{Motivasi Pelestarian Seni Budaya}

Berdasarkan penelitian yang telah dilakukan dan data-data yang dikumpulkan, ada beberapa hal yang dapat ditarik berdasarkan fenomena yang ada yaitu diantaranya masyarakat Desa Adat Sidan sangat terbuka dalam memberikan informasi terkait dengan wayang wong di desa mereka. Walaupun dalam kenyataannya cukup sulit dalam 
mencari talenta baru atau regenerasi penari, dukungan dari masyarakat berdampak pada semangat antusiasme calon penari. Dukungan tersebut tidak hanya dari masyarakat setempat, namun ada pula dari pemerintah Kabupaten Badung. Adanya akumulasi serta tindakan-tindakan yang positif terhadap wayang wong desa, secara tidak langsung memunculkan indikasi-indikasi pelestarian budaya pada desa setempat. Asumsi adanya tindakan dalam memotivasi pelestarian budaya, muncul juga berdasarkan rangkuman pada data wawancara yang telah dilakukan selama penelitian dan interaksi peneliti dengan masyarakat setempat. Oleh sebab itu muncul gagasan peneliti untuk menyerahkan data video berikut dengan master data yang dimiliki. Hal ini guna melanjutkan harapan motivasi pelestarian budaya setempat dalam bentuk video dokumenter. Sehingga tindakan pelestarian dapat berjalan secara berkelanjutan khususnya di Desa Adat Sidan Kecamatan Petang Kabupaten Badung.

\section{KESIMPULAN}

Berdasarkan penelitian yang telah dilakukan, kesimpulan yang dapat dirumuskan adalah sebagai berikut: a) Perancangan video dokumenter tentang wayang wong Desa Adat Sidan ini harus melalui proses yang terstruktur dan terencana sehingga hasil luaran dapat maksimal. b) Perancangan video dokumenter ini, selain mengedepankan etika dalam penelitian juga perlu mengedepankan etika bersosialisasi dalam masyarakat. Sehingga data yang ingin digali dapat dikumpulkan dengan mudah tanpa kesulitan yang berarti. c) Pada pengumpulan data serta analisis tentang data yang didapatkan, ternyata memunculkan indikasi lain yaitu asumsi adanya tindakan pelestarian budaya yang secara tidak langsung telah dilakukan oleh masyarakat setempat ataupun peneliti.

Berdasarkan durasi penelitian terdapat beberapa hal yang bisa digali kembali sekaligus menjadi saran untuk keberlanjutan penelitian khususnya tentang wayang wong dari Desa Adat Sidan ini yaitu pertama, implementasi media perlu dikembangkan atau sangat berpeluang penelitian ini diimplementasikan ke dalam bentuk berbeda selain video dokumenter. Kedua, penelusuran tentang tradisi budaya, tidak hanya ada pada kesenian wayang wong saja. Terakhir, sangat memungkinkan adanya fenomena sosial terkait prosesi ataupun terkait dengan wayang wong dalam berbagai disiplin ilmu yang berhubungan.

\section{DAFTAR PUSTAKA}

Badung., K. (2019). Tarian Wayang Wong Sasih Dilestarikan di Br. Sidan. Retrieved August 10, 2019, from https://desabeloksidan.badungkab.go.id/bacaberita/5857/Tarian-wayang-wong-masih-dilestarikan-di-br-sidan.htm

Badung, B. P. S. K. (2018). Kecamatan Petang Dalam Angka 2018. Badung: BPS Kab. Badung.

Bandem, I. M. (1983). Ensiklopedi Tari Bali. Denpasar: Akademi Seni Tari Indonesia.

Basrowi, S. (2002). Metode Penelitian Kualitatif Perspektif Mikro. Surabaya: Insan Cendekia.

Binanto, I. (2010). Multimedia Digital - Dasar Teori dan Pengembangannya. C.V Andi Offset. Yogyakarta: Andi.

I Made Bandem; Murgiyanto. (1996). Teater Daerah Indonesia. Yogyakarta: Kanisius. 
Kusharyani, M.; Santoso, B. . W. (2016). Eksistensi dan Perlindungan Wayang Orang Sriwedari Surakarta Ditinjau dari Aspek Hukum Hak Cipta. Psychol Bull, 2(1), 60-72. Setiawan, I. N. A. F. (2018). Sinema Paradoks : Pengantar dan Konteks Kontemporer. (I. N. Jayanegara, Ed.). Denpasar: STMIK STIKOM Indonesia.

Soedarsono, R. M. (2002). Seni Pertunjukan Indonesia di Era Globalisasi. Yogyakarta: Gadjah Mada University Press.

Sonalitha, E., Yuniarti, S., Prihatiningsih, B., \& Prasetya, A. Y. (2017). Peningkatan Pelestarian Seni Tari Wayang Orang Melalui Video Pembelajaran. Jurnal ABDIMAS Unmer Malang, 2(1), 63-69.

Sule, Ernie Tisnawati \& Saefullah, K. (2006). Pengantar Manajemen. Jakarta: Prenada Media.

Supendi, E. (2007). Wayang Orang Sebagai Pertunjukan Teater Tradisional Dalam Tinjauan Semiotika: Sebuah Kajian Awal. Gelar, 5(1), 54-72.

Sutrisno, E. (2009). Manajemen Sumber Daya Manusia Edisi pertama. Jakarta: Kencana Prenada Media Group.

Taksu, B. (2019). Tari Bali - Jenis Tari Wali (Wali, Bebali, Balih-balihan). Retrieved August 10, 2019, from https://balitaksu.com/tari/jenis-id 